\title{
The Observing Learning Activity Assisted by Concrete Media Improves Student's Conceptual Knowledge
}

\author{
I Made Tegeh ${ }^{1^{\star}}$, I Gusti Lanang Agung Parwata ${ }^{2}$, Bernadeth Grace Ostaviani ${ }^{3}$ \\ ${ }^{1}$ Education Technology, Universitas Pendidikan Ganesha, Singaraja, Indonesia \\ 2Physical Education, Health and Recreation, Universitas Pendidikan Ganesha, Singaraja, Indonesia \\ ${ }_{3}^{3}$ Primary School Education Teachers, Universitas Pendidikan Ganesha, Singaraja, Indonesia \\ e-mail: im-tegeh@undiksha.ac.id, agung.parwata@undiksha.ac.id, bernadethgrace@yahoo.com
}

\begin{abstract}
The purpose of this study was to examine the effect of observing learning activities assisted by concrete media in a scientific approach toward the conceptual knowledge of the fifth-grade students. This study was a quasi-experiment with a post-test only control group design. The population of this study was all students of the fifth grade of Public Elementary School (SDN) 4 Cempaga and Public Elementary School (SDN) 4 Kawan. The samples were taken by purposive sampling. Conceptual knowledge data were collected by using multiple-choice tests. The obtained data were analyzed using a t-test. Based on the results of the t-test analysis, it was obtained tcount $=11.36$ while the table value was 2. 021 . Based on tcount $=11.36>t_{\text {table }}=2$. 021 then $H_{0}$ was rejected. The results of the analysis prove that there are significant differences between a group of students who are taught by observing learning activities assisted by concrete media and a group of students who are taught by conventional learning. In addition, the average value of the experimental group learning outcomes is $\bar{X}=22.30$ which is higher than the average learning outcomes of the control group $\bar{X}=18.40$. From the results of the $t$ test analysis and the average learning outcomes, it can be concluded that observing learning activities assisted by concrete media influence the conceptual knowledge of the fifth-grade students. Therefore, observing learning activities assisted by concrete media are suitable to be applied to overcome the low conceptual knowledge of students. This finding will have implications, namely, to improve conceptual knowledge can be done by observing activities assisted by concrete media so the learning activities will be more meaningful and interesting
\end{abstract}

Keywords: Observing Learning Activities; Concrete Media; Conceptual Knowledge

\section{Introduction}

The implementation of school learning is currently referring to Curriculum 13 (K13) which involves a scientific approach in each subject, including the most emphasized science subjects. A scientific approach is a scientific activity that includes observing, questioning, collecting information, associating, and communicating (Sari, et al., 2018). Limiansih (2013) also states that the learning implementation of scientific approach involves students to explore their knowledge. The scientific approach involves students to practice and think critically to solve problems as well as trained to be a scientist (Arisanti et al., 2016). By being trained to think critically from an early age, students are expected to be innovative and competitive individuals (Windyariani, 2018). Along with the scientific approach of learning activities, it is no longer conducted by the teacher center but rather the student center so students explore their knowledge through the components of the scientific approach, and learning can be said to be effective.

The scientific approach is closely related to the implementation of the knowledge dimension including conceptual, procedural, and factual knowledge. These three dimensions are integrated with the implementation of daily learning (RPP). However, reality shows that the proportions of the average values of each dimension are not the same. Moreover, the conceptual knowledge dimension tends to have the lowest average (Sani, 2016; Dewi, 2016).

\footnotetext{
* Corresponding author.

Received 10 Mei 2020; Accepted 4 June 2020; Available online 20 June 2020

(C) 2020 JPI. All Rights Reserved
} 
The understanding of the conceptual knowledge dimension is very important, because by understanding/mastering the concept, it will facilitate students in learning the dimensions of procedural knowledge, then to metacognition (Flaig et al., 2018). The mastery of concepts must be emphasized in every learning so that the students have a good basic provision to achieve other abilities such as reasoning, communicating, connecting, and problem solving (Suhito, 2018). The conceptual knowledge certainly becomes the basis that must be known by students and it requires teachers to strive the learning that can be easily understood by students either by using more innovative learning models or assisted by media. Therefore, students' conceptual knowledge can increase.

Yusuf and Prabowo (2019) reveal the conceptual knowledge as a knowledge that can help every student to transfer what they have learned in the new situations. The knowledge measurement process of students ' success level uses a method in the form of a test. The used test is an objective test (multiple choice). This test is given to the students in finding out the conceptual knowledge possessed by students based on Revised Bloom's Taxonomy theory. From the way of test, it will be known how the students' conceptual knowledge in learning the scientific approach reviewed from six aspects, namely remembering, understanding, applying, analyzing, evaluating, and creating using a test method. Anderson and Krathwohl (2010) states that the category of cognitive aspect is divided into six aspects, namely remembering (C1), understanding (C2), applying (C3), analyzing (C4), evaluating (C5), and creating (C6). The teacher makes the result of this study as one of the references to increase the learning activities to be more interesting, motivating, and enjoyable in thematic learning of Elementary Schools. However, the reality is inversely proportional to what is expected.

There are still many phenomena in school that the learning implementation does not consider the characteristics of elementary school-age children who can not think abstractly and like physical activity. Learning is only focused on the concept and does not pay attention to the importance of inculcating scientific skills and students' attitudes. It makes many students gain knowledge that they do not understand and mean. It is difficult for them to relate it to what is happening in their daily lives (Jayanta, 2017). This is supported by the result of observation and interview in 2017 in Cluster III Bangli Regency, the problem faced by the fifth-grade students is the same, namely the causes of low students' learning outcomes, one of them is due to the low students' conceptual knowledge. It can be seen from the result of students' midterm exams as shown in Table 1.

Table 1. The Result Score of Students' Midterm Exam

\begin{tabular}{cccccc}
\hline & \multirow{2}{*}{$\begin{array}{c}\text { Elementary } \\
\text { School }\end{array}$} & $\begin{array}{c}\text { The Mean } \\
\text { Score of } \\
\text { Midterm Exam }\end{array}$ & Conceptual & Factual & Procedural \\
\cline { 4 - 6 } & SD N 1 Kawan & 66,48 & 50 & 75 & 75 \\
\hline 1 & SD N 4 Kawan & 66,42 & 45 & 75 & 70 \\
2 & SD N 6 Kawan & 63,58 & 55 & 75 & 75 \\
3 & SD N 1 Cempaga & 63,71 & 45 & 70 & 85 \\
4 & SD N 2 Cempaga & 66,02 & 50 & 65 & 75 \\
5 & SD N 4 Cempaga & 67,96 & 45 & 80 & 75 \\
\hline 6 & Sluster Mean & 65,69 & 48,33 & 73,33 & 75,83 \\
\hline
\end{tabular}

Based on Table 1, it can be seen that the level of students' conceptual knowledge is still low. Many factors can cause problems to lower the average of students' conceptual knowledge. The teacher factor as a concept planner is very influential in this case. The teacher is still resistant toward teaching demands with a scientific approach and student center in $\mathrm{K} 13$ implementation (Windyariani, 2018). The teacher does not go deep into teaching performance due to the lack of mastering material and using a conventional method. Thus, it has an impact on learning effectiveness. One of the impacts is the understanding of students' conceptual knowledge which tends to be low. Then, the conventional learning that is conducted is still 
only based on books without using assistance in the form of media because the media supply at the school is still very low as well as the procurement of media is conducted rarely.

During this time, when the learning activities using science make students less understand the material explained by the teacher. This is shown by the students' behavior who always asks questions about the material delivered by the teacher in front of the class, so the students rarely follow the learning enrichment. It is in line with the opinion of Thobrone \& Mustofa (Sudiarti, 2015) in constructivism learning theory which views the cognitive development of children can build their knowledge and understand social reality based on their interaction experience. Those problems have an impact on students' conceptual knowledge to improve students' conceptual knowledge, it needs innovation to be applied especially in observing activities in the learning process.

According to Khamidah (2017), conceptual knowledge is a given concept for students to find out what can be considered and cannot be considered as an example. Arnidha (2016) states that conceptual knowledge is a knowledge that has a lot of connectedness among pieces of information in the form of facts, skills, concepts, and principles that can be seen as a knowledge network that has a relationship one to another. Yusuf and Prabowo (2019) reveal that conceptual knowledge is a knowledge that can help every student as they try to transfer what they have learned to the new situations.

One of the learning strategies that can be applied to improve conceptual knowledge, especially in the process of observing, is assisted with concrete media. Mahendrawati, et al (2016) reveal that the concrete media is the media that is either original or imitation which is useful for the process of inculcating concepts for students. This is in line with Trianto (2010) which states that concrete media provides concrete visual assistance to help to organize information before the information is learned. Arylien and Josua Bire (2014) argue that by observing something real, students will be faster in understanding the material. In line with the opinion above which is internationally recognized and has been translated, Chiou (2008) suggests that the concrete media is used as a strategy to help students in organizing their cognitive frameworks into a stronger integrated pattern. Rahayu, et al (2016) in their research revealed that the concrete media could improve the learning outcomes of Natural Sciences themed my house' of the fourth grade B at SD Negeri 6 Keisma. Mahendrawati, et al (2016) in his research also found a significant difference in learning using concrete media with those who were not taught using concrete media. Hardini and Arlita (2017) in their research revealed that by using concrete media, students were more active and happy to participate in learning. Therefore, the learning implementation assisted by concrete media is expected to have a positive impact on improving students' conceptual knowledge.

Nowadays the concrete media has experienced a lot of development both in terms of form, design, and the addition of relevant functions to follow the students' development. When it is compared to the previous conventional media, the current creative media are more directed at the efficiency of function and usability, the development of shapes and designs that follow technology development (García Coni et al., 2019). So it looks more modern, function optimally and innovatively, and with recycled materials. The examples of concrete media are educational play tools (EPT) and teaching aids (Congdon et al., 2018).

Observing the situation in the field that the conventional learning models with lecture methods are still used, the use of concrete media is very well to be used. Thus, the solution that can be offered to overcome problems is by using concrete media to increase students' conceptual knowledge. Concrete media are real objects that provide important stimuli for students in learning various things, especially those related to the development of certain skills (Erowati, 2015; Dwipayanti, 2013). Riyanto (2014) states that concrete media is suitable and very good media to explore students' initial knowledge. Rahayu et al. (2016) in their research revealed that the concrete media can improve the learning outcomes of the Natural Sciences theme 'my house' of the fourth grade B student at SD Negeri 6 Keisma. Mahendrawati et al. (2016) in their research also found that there were significant differences in learning using concrete media and those who were not taught by using concrete media. Hardini and Arlita (2017) in their research revealed that by using concrete media, the students were more active and happy to participate in learning. Therefore, the implementation of the learning assisted by 
concrete media is expected to have a positive impact to improve students' conceptual knowledge.

Based on the explanation above, this study aimed at examining the observing learning activities assisted by concrete media in a scientific approach to the conceptual knowledge of elementary school students in the fifth grade.

\section{Method}

This study applied an experimental research method. The research design used in this study was a non-equivalent post-test only control group design because the experiments did not allow to change the existing design class (Agung, 2010). The implementation of the research design with this type, the experimental group was given a treatment of learning with observing activities assisted by concrete media the control group was treated with conventional learning. Both the experimental group and control group were given a post-test to find out the differences in learning outcomes between the experimental groups who were treated with active learning activities and assisted with concrete media and the control groups who were not treated with conventional learning. The research procedure included several stages. The first stage of preparation consisted of observing the environment and research material, determining research material, conducting a study of research material, determining population, and research samples, taking care of research permits. Second, the implementation phase, consisting of the learning phase, the posttest stage. And the last stage is evaluation and report making.

The population of this study was all the fifth-grade students in Cluster III of Elementary School in Bangli Regency with a total population of 141 people that were divided into 6 classes. This sampling applied a purposive sampling technique. Schools are selected based on certain criteria, namely schools that implement the 2013 curriculum. To ensure this school is equal, an equality test with a t-test was conducted. Then, the result showed that SD N 4 Cempaga as an experimental class and 4 Friends as a control class. The samples were taken by purposive sampling which amounted to 44 students divided into two classes.

The students' conceptual knowledge in thematic learning on the theme of Our Friends Environment was the data that was looked for. Data collection methods were multiple-choice objective tests total with 30 objective questions. Post-tests were given when both the experimental class and the control class were given treatment. The experimental class was treated by observing learning activities assisted by concrete media, while the control class was given treatment by implementing learning activities using a conventional learning model.

This test instrument had been tested to ensure the quality of the instrument's viability, namely through validity test with experts/experts, item validity analysis, reliability analysis, differentiation analysis, and difficulty level analysis. The validity test was conducted by the expert and got the results that all items were relevant. Based on validity test, test items of 58 respondents from students, it obtained 43 valid test items from 25 test items were tested, and from 43 valid test items, it was used 30 items as a post-test. Then, for reliability test, it obtained a result of 0.926 so it can be said that the tested instruments were classified as very high. Furthermore, for the questions level difficulty, it obtained 10 items that were classified as easy, and 20 items were classified as moderate. And for the results of different power test, it obtained 7 items were classified as sufficient, 6 items were classified as good, and 17 items were classified as very good. Furthermore, the data analysis that had been collected using inferential statistics in the form of prerequisite tests and t-tests to find out the truth of the hypothesis that there were differences between students in the experimental group and students in the control group.

\section{Result and Discussion}

\subsection{Research Result}

The hypothesis in this study was analyzed using a t-test. However, to provide an overview of the data distribution, this study applied a descriptive analysis by determining firstly the mean, median, mode, and standard deviation. The mean, median, mode, and standard deviation in the control and experimental classes as presented in the table below. 
Table 2. Mean, Median, Mode, and Standard Deviation

\begin{tabular}{lcc}
\hline \multirow{2}{*}{ Statistic } & \multicolumn{2}{c}{ Conceptual Knowledge } \\
\cline { 2 - 3 } & Experimental Class & Control Class \\
\hline Mode & 24,21 & 17,99 \\
Median & 23,62 & 18,25 \\
Mean & 22,30 & 18,40 \\
Standard Deviation & 4,03 & 3,19 \\
Variance & 16,25 & 10,22 \\
\hline
\end{tabular}

Based on observing learning activities assisted concrete media given to the experimental group. The result data of the thematic lesson post-test themed environment our friends sub-themes 2 and 3 of 22 students of the experimental group, showed that the highest score was 30 and the lowest score was 14, and in the control group of 20 students, it showed that the highest score was 26 and The lowest score was 12. The calculated results were set for the interval number or the length of the class interval of the experimental class and the control class was 3 and the number of the experimental class was 6 , while the number of control class was 5 (Table 3).

Table 3. The Frequency Distribution of Post-Test Result of Experimental and Control Group

\begin{tabular}{cccccc}
\hline $\begin{array}{c}\text { Experimental } \\
\text { Interval Class }\end{array}$ & $\begin{array}{c}\mathbf{F} \\
\text { Experiment }\end{array}$ & $\begin{array}{c}\mathbf{f x} \\
\text { Experiment }\end{array}$ & $\begin{array}{c}\text { Control } \\
\text { Interval Class }\end{array}$ & F Kontrol & fx Kontrol \\
\hline $14-16$ & 2 & 30 & $12-14$ & 1 & 13 \\
$17-19$ & 2 & 36 & $15-17$ & 7 & 112 \\
$20-22$ & 4 & 84 & $18-20$ & 8 & 152 \\
$23-25$ & 8 & 176 & $21-23$ & 3 & 66 \\
$26-28$ & 5 & 135 & $24-26$ & 1 & 25 \\
$29-31$ & 1 & 30 & & $\sum \mathrm{f}=20$ & $\sum \mathrm{fX}=368$ \\
\hline
\end{tabular}

The results of these calculations, it was known that the number of students who got a score between 14 and 16 was 2 students, students who got a score between 17 and 19 were 2 students, students who got a score between 20 and 22 were 4 students, students who got a score between 23 and 25 were 8 students, students who got a score 26 to 28 were students, and students who got a score 29 to 31 were 1 student and in the control group, it was known that many students got a score between 12 and 14 was 1 student, students who got a score between 15 and 17 were 7 students, students who got a score between 18 and 20 were 8 students, students who got a score between 21 and 23 were 3 students, students who got score 26 to 26 was 1 student. The results of the data described above had been calculated with tendential thickness, namely, mean, median, mode, and standard deviation. Thus, the mean obtained from the experimental group was 22.30 the median was 23.62 , and the mode was 24.21, the standard deviation (s) of the experimental group data was 4. 03. Meanwhile, the results of the data described in the control group, the mean data was 18.40, the median was 18.25, and the mode was 17.99, the standard deviation (s) of the control group's data was 3.19. After that, five scales assessment were conducted with the average of conceptual knowledge score of the experimental group students belonged to very high category (24.21> 23.62> 22.30) and the average of conceptual knowledge score of the control group students belonged to high category $(17.99<18.25<18.40)$.

Before testing the hypothesis with an independent t-test, firstly, the testing of prerequisites was required for research data distribution. The analysis of the prerequisite test consisted of two things, namely (1) normality test of data distribution of the whole analysis unit, and (2) homogeneity tests of variance between groups

Data normality test was performed on the entire unit of analysis, namely the experimental group and control group. Data normality provisions were determined by looking at the significance analysis result. The data is normally distributed if the obtained significance 
level is more than 0.05 at the significance level of $5 \%$. Based on the data analysis, the results of the normality test distribution of post-test results of the experimental group and the control group can be presented in the following Table 4.

Table 4. The Result of Data Distribution Normality Test

\begin{tabular}{clccc}
\hline No. & $\begin{array}{c}\text { The Ability Group Data of Mathematics } \\
\text { Solving Problem }\end{array}$ & $\chi^{2}$ & $\begin{array}{c}\chi^{2} \text { table } \\
\text { with Significance } \\
\text { Level 5\% }\end{array}$ & Status \\
\hline 1 & Experimental Post-test & 4,5286 & 7,815 & Normal \\
2 & Control Post-test & 2,093 & 5,591 & Normal \\
\hline
\end{tabular}

The results of calculations using the Chi-Square formula $\left(\chi^{2}\right)$, the calculated value $\left(\chi^{2}\right)$, of the experimental group post-test around 4.5286, and the $\left(\chi^{2}\right)$ table with freedom degrees ( $\mathrm{fd}$ ) $=3$ at a significance level of $5 \%$ was 7,815 . It means that the $\left(\chi^{2}\right)$ count experimental group posttest result was smaller than $\left(\chi^{2}\right)$ table $(4.5286<, 7.815)$ so the experimental group post-test result was normally distributed. Meanwhile, $\left(\chi^{2}\right)$ count the control group's post-test result was 2.093 , and $\left(\chi^{2}\right)$ table with freedom degrees $(\mathrm{fd})=2$ at a significance level of $5 \%$ was 5.591 . It meant that the control group's post-test results were smaller than $\left(\chi^{2}\right)$ table $(2,093<5.591)$ so the control group's post-test result was normally distributed.

The homogeneity variance test was performed based on conceptual knowledge data of the experimental group and control group. The number of units of analysis was 22 and 20 students. The homogeneity variance test between groups using $\mathrm{F}$ test. Data were declared homogeneous if $F_{\text {count }}<F_{\text {table. }}$. The summary of the variance homogeneity can be seen in Table 5.

Table 5. The Test Result Summary of Variance Homogeneity of Experimental and Control Groups

\begin{tabular}{|c|c|c|c|}
\hline Data Source & $F_{\text {count }}$ & $\begin{array}{c}F_{\text {table }} \text { with Significance } \\
\text { level of } 5 \%\end{array}$ & Status \\
\hline $\begin{array}{c}\text { Experimental and Control Group } \\
\text { Post-test }\end{array}$ & 1,699 & 2,16 & Homogeneous \\
\hline
\end{tabular}

It can be seen that the results of experimental and control group post-test with the numerator $\mathrm{db}=22-1=23$ and the denominator $\mathrm{db}=20-1=19$ at significance level of $5 \%$ was known $F_{\text {table }}=2.16$ and $F_{\text {count }}=1.699$. It meant that $F_{\text {count }}<F$ table $(1,699<2.16)$ so the students' conceptual knowledge data was homogeneous. After that, the research hypothesis test was conducted.

Based on the data of the distribution normality test and variance homogeneity test, it was found that the conceptual knowledge of the experimental group and control group students was normally distributed and homogeneous. Based on this case, then it proceeded to the research hypothesis testing.

The hypothesis testing used an independent group t-test (not correlated) with the polled variance formula.

$\mathrm{H}_{0}$ : There was no significant difference in conceptual knowledge result between students who were taught by learning activities assisted concrete media and students who were taught by conventional learning in the fifth-grade students of Cluster III Bangli Regency Academic Year of 2016/2017.

$\mathrm{H}_{1}$ : There was a significant difference in conceptual knowledge results between students who were taught by learning activities assisted concrete media and students who were taught by conventional learning in the fifth-grade students of Cluster III Bangli Regency Academic Year of 2016/2017. The hypothesis testing used an independent group t-test (not correlated) with the polled variance formula. The result of the hypothesis test was presented in Table 6. 
Tabel 6. The Summary of Hypothesis Test Result

\begin{tabular}{|c|c|c|c|c|c|c|}
\hline $\begin{array}{c}\text { Data Group of Problem- } \\
\text { Solving Ability }\end{array}$ & $\begin{array}{l}\text { Variance } \\
\quad\left(s^{2}\right)\end{array}$ & $\mathbf{N}$ & $\begin{array}{c}D b \\
\left(n_{1}+n_{2}-2\right)\end{array}$ & $\mathbf{T}_{\text {count }}$ & $\begin{array}{c}\mathbf{F}_{\text {table }} \text { with } \\
\text { Significance } \\
\text { level of } 5 \%\end{array}$ & Conclusion \\
\hline Experimental Group & 1625 & 22 & \multirow{2}{*}{40} & \multirow{2}{*}{11,36} & \multirow{2}{*}{2,021} & \multirow{2}{*}{$\begin{array}{c}\mathrm{t}_{\text {count }}>\mathrm{t}_{\text {table }} \\
\left(\mathrm{H}_{0} \text { rejected }\right.\end{array}$} \\
\hline Control Group & 10,22 & 20 & & & & \\
\hline
\end{tabular}

From the results of t-test calculations, thus, it can be interpreted that there was a significant difference in students' conceptual knowledge between students who were taught by observing learning activities assisted by concrete media and students who were taught by conventional learning in the fifth-grade students of Cluster III Bangli 2016/2017.

The results of research data that have been tested and hypothesis testing concerned with the conceptual knowledge of the fifth-grade students who took part in observing learning activities observing assisted by concrete media and conventional learning on our friend's environment theme, Subtheme 2 and 3 . Based on the average score of students' conceptual knowledge and t-test results. The average score of conceptual knowledge of experimental group students in which the learning activities assisted by concrete media was 22.30 in the very high category, while the average score of conceptual knowledge of control group students who were taught by conventional learning was 18.40 in the high category. The results of data analysis using the t-test obtained $t_{\text {count }}=11.50$ and $t_{\text {table }}=2.021$ for $\mathrm{db}=40$ with a significant level of $5 \%$. Based on the results of these calculations showed the $t>t$ table, so $\mathrm{H}_{0}$ was rejected and $\mathrm{H}_{1}$ was accepted. It showed that there was a significant difference in students' conceptual knowledge between students who were taught by observing learning activities assisted by concrete media and students who were taught by conventional learning in the fifthgrade students of Elementary School of Cluster III Bangli Regency Academic Year of 2016/2017.

\subsection{Discussion}

The results of this study found that there were differences between students' conceptual knowledge toward a group of students who were taught by observing learning activities assisted by concrete media and a group of students who were taught by conventional learning models. Based on the average value of conceptual knowledge, the group who used observing learning activities assisted by concrete media showed 22.30 higher than the mean and the results of conceptual knowledge from the group learned with a conventional learning model around 18.40. Regarding this matter, it can be seen that observing learning activities assisted by concrete media have a positive effect on the conceptual knowledge of the fifthgrade students of Cluster III Bangli Regency. The results of this study indicate that the students who were given observing learning activities assisted by concrete media $58.62 \%$ of students get high grades and very high categories, $37.93 \%$ of students get grades with medium categories, $6.90 \%$ of students get low grades, and very low. This variation shows that conceptual knowledge is not only influenced by the learning model factors provided by the teacher.

This study proves that using concrete media raises students' self-confidence, learning motivation, students' talents, students' economic conditions, school management, and school climate. This reinforces the theory states that the influenced factors of learning achievement can be classified into two groups, namely internal factor that comes from students and external factor that comes from outside of students (Slameto, 2003; Sudjana, 1990; Sugihartono, 2007). Based on the analysis results, various things cause a significant difference in students' conceptual knowledge between students who have concrete media in learning activities and students who learn in conventional learning. This is due to the treatment in the learning process. In conventional learning, it is characterized by lecturing, questions and answers, exercises, and assignments, the teacher dominates in learning so it is centered on the teacher 
(teacher-centered). In line with Putrayasa (Sudiarti, 2015) states that conventional learning is learning where the teacher initiates learning, then does questions and answers, gives assignments, and do tasks by students until the teacher feels that the material has been understood by students. Learning activities are very important for the interaction between teacher to students and students to teachers, it supports the learning process to receive the material maximally.

Learning activities in this scientific approach involve students in direct activities and help students to connect academic learning with the real-life context that is faced, so students are expected to be more creative, innovative and able to bring out a bright idea for solving the problem (Firman et al., 2018). In the scientific approach, there are many components, one of them is observing learning activities (Marjan et al., 2014; Daryanto, 2014). Observing is an activity that is conducted deliberately and systematically to learn about social phenomena or real objects through the use of the five senses (Nugraha \& Didi, 2017). In observing learning activities, the students absorb material that is delivered by the teacher, this is the importance of interaction between teacher to students and students to teachers. The interaction refers to the clarity of delivering material to students, if it only uses lecturing without the assistance of media, students tend to less understanding of the learning material being taught. The lack of students' understanding will affect the students' conceptual knowledge itself. Conceptual knowledge can be defined as a learning process with an understanding that requires more than just memorizing a material, so learning can be said to be more meaningful learning (Saricayir et al, 2016). Besides, the learning process uses lecturing tends to make students get bored quickly and learning is not interesting. Thus, students will not focus during the learning process and the material cannot be conveyed properly, especially material related to students' conceptual knowledge. It will cause students' conceptual knowledge to be not optimal.

In contrast to observing learning activities assisted by concrete media, because it requires students' understanding in reaching the material assisted by concrete media, in concrete media learning, the materials are structured in such a way that students are easy to absorb material taught by the teacher, this is in line with the opinions of Asan experts (2007) are taken from international journals and translated, state a concrete media is used to visualize the structure of knowledge so the memory will last longer. From those activities, the students can more easily absorb the material delivered by the teacher, then the interaction between teacher and students is optimal.

Observing learning activities assisted by concrete media make it easier for students to digest the material in observing learning activities, more enthusiastic to learn so students can build their knowledge. Students become more structured to digest learning material, so students understand easily the material that has been studied. It is also due to the ability of students' thinking at the elementary school level has not yet reached the level of abstract thinking. Therefore, the application of concrete media is a very positive influence during learning to further maximize the learning objectives to be achieved and learning can be more meaningful. Also, students will more easily understand the material and can store it in longterm memory. Thus, students' conceptual knowledge taught by observing learning activities assisted by concrete media is better than conceptual knowledge taught by conventional learning.

The learning process in the classroom which initially explained guided by books without using media has now shifted towards a better way of using media of mapping concept. Initially learning focuses on books and teachers as subjects, students only as objects. The application of this learning changes to more focused on students. Previously, the students receive material in an unstructured way, but now students become more receptive to the material in a structured way, students' learning activeness will be increased because students conceptualize their knowledge by observing the material that is discussed.

The results of this study are in line with the results of several kinds of research on the mapping concept. Ni Luh Jayanti (2014) shows that the effect of learning cycle 5e learning model assisted by concrete media can affect the conceptual knowledge of science in the fifthgrade students of SD Negeri 2 Tibubeneng Badung. The analysis of this study shows that 
there is a significant difference in the conceptual knowledge of science between students who are taught using the Learning Cycle 5 Learning model assisted by concrete media and those who are taught conventionally in the fifth grade of SD Negeri 2 Tibubeneng Badung.

Secondly, Wayan Juniasih (2015) shows that the effect of pq4r learning strategies assisted by concrete media differs significantly from the conceptual knowledge of science students who follow conventional learning models. The analysis of this study shows that there are significant differences on the conceptual knowledge of science between groups of students who learn by using PQ4R learning strategy assisted by concrete media and groups of students who learn by conventional learning models in the fourth grade in even semester academic year of 2014/2015 in Cluster II, Buleleng District, Buleleng Regency.

These findings will have implications to increase students' conceptual knowledge, the use of observing activity assisted by concrete media can be considered as an alternative to creating a pleasant learning atmosphere so it can provide a good solution in learning activities to improve students' conceptual knowledge, especially in elementary school student.

\section{Conclusion}

Based on the calculation results of average value, the conceptual knowledge of the groups who learn using observing learning activities assisted by concrete is 22.30 higher than the groups who learn using conventional learning models around 18.40. The result of this study indicates that in groups of students taught by observing learning assisted by concrete media $58.62 \%$ of students get grades with high and very high categories, $37.93 \%$ of students get grades with medium categories, $6.90 \%$ of students get low grades, and very low. Based on the explanation of the results and discussion above, it can be concluded that observing learning activities assisted by concrete media affects students' conceptual knowledge to enhance student understanding.

\section{References}

Agung, A. A. Gede. 2010. Metodologi Penelitian Pendidikan. Singaraja: Fakultas IImu Pendidikan Undiksha.

Anderson, dan Krathwohl. (2010). Pembelajaran, Pengajaran, dan Asesmen. Yogyakarta: Pustaka Belajar.

Arnidha, Yunni. 2016. Analisis Kemampuan Pengetahuan Konseptual Dan Prosedural Siswa Sd Dalam Pokok Bahasan Pecahan. JPGMI. Vol. 2 No 1.

Arylien, Josua. (2014). Pengaruh Gaya Belajar Visual, Auditorial, Dan Kinestetik Terhadap Prestasi Belajar Siswa. Jurnal Kependidikan, 44(2) November 2014

Asan, Askin. (2007). Media Concret in Science Class: A Case Study of Fifth Grade Students. Sultan Qaboos University, 10(1) 186.

Chiou, Chei-chang. (2008). The Effect of Media Concret on Students' Learning Achievements and Interests. Innovations in Education and Teaching International, 45(4)2.

Daryanto. (2014). Pendekatan Pembelajaran Saintifik Kurikulum 2013. Yogyakarta: Gava Media

Dwipayanti, N. A., Sudhita, I. W. R., \& Parmiti, D. P. 2013. Pengaruh Model Pembelajaran Addie Berbantuan Media Konkret Terhadap Hasil Belajar IPA Siswa Kelas V SD Negeri 1 Pangkungparuk, (3)

Erowati, Tri. "Pengaruh Penggunaan Media Konkret Terhadap Hasil Belajar IPA Siswa Kelas IV di SDN Sumberejo 01". Jurnal Pendidikan Universitas Sebelas Maret dan ISPI Wilayah Jawa Tengah.

Ganesha, U. P. (2013). Pengaruh Model Pembelajaran Think Talk Write (TTW) Berbantuan Media Konkret Terhadap Hasil Belajar IPA Siswa Kelas IV SD

Jayanta, Laba, dkk. "The Discrepancy of Curriculum 2013 in Teaching and Learning Process Based on Permendikbud No 65 of 2013 in SD Laboratorium Undiksha". Journal of Education Research and Evaluation. Vol. 1 (2) pp. 73-81. Diakses pada tanggal05 Mei 2017 
Jayanti, Made. (2015). Pengaruh Strategi Pembelajaran Pq4r Berbantuan Media Konkret Terhadap Pengetahuan konseptual IPA Siswa Kelas IV SD. Jurnal Mimbar PGSD Universitas Pendidikan Ganesha, 3(1)2015

Koriagung, Cahyani. (2015). Penerapan Media Konkret Dalam Pendekatan Saintifik Untuk Meningkatkan Pengetahuan konseptual PKN dan Pengetahuan Faktual Pada Tema Cita-Citaku Siswa Kelas IVbSD Negeri 5 Tonja. Jurnal Mimbar PGSD Universitas Pendidikan Ganesha, 3(1) 2015

Kristiani, Novi (2016). "Keefektifan Pembelajaran Matematika Melalui Penggunaan Media Benda Konkret Pada Kelas V SD Timuran". Jurnal Prima Edukasia Vol 4 Nomor 2 Juli $2016(163-175)$

Limiansih. K. 2013. "Analisis Buku: Apakah Kegiatan di Buku Siswa Kelas IV SD Kurikulum 2013 Telah Mendukung Pembelajaran IPA dengan Pendekatan Saintifik?" Prosiding Seminar Nasional Inovasi Pendidikan Inovasi Pembelajaran Berbasis Karakter dalam Menghadapi Masyarakat Ekonomi ASEAN. Halaman (115-137). Diakses pada tanggal 26 januari 2017.

Mahendrawati, dkk. 2016. Pengaruh Model Contextual Teaching and Learning Berbantuan Media Konkret Terhadap Hasil Belajar Matematika Kelas V. eJournal PGSD Universitas Pendidikan Ganesha Jurusan PGSD Vol: 4 No: 1

Mangesa, Riana T. (2016) Implementasi Pendekatan Kontekstual Dalam Pembelajaran Praktik Instalasi Listrik. Jurnal Kependidikan, 46(1) Mei 2016.

Marjan, J., Arnyana, I. B. P., \& Setiawan, I. G. A. N. Johari Marjan (2014). Pengaruh Pembelajaran Pendekatan Saintifik Terhadap Hasil Belajar Biologi dan Keterampilan Proses Sains Siswa MA Mu' allimat NW Pancor Selong Kabupaten Lombok Timur Nusa Tenggara Barat. Program Studi Pendidikan IPA, Program Pascasarjana, 4

Niron, Sesilia Kendari. (2016). Pelaksanaan Pendekatan Saintifik dalam Pembelajaran di Kelas IV SD Negeri Nirmala Kabupaten Bantul. Yogyakarta: Universitas Negeri Yogyakarta. Jurnal Pendidikan Guru Sekolah Dasar Edisi 7 Tahun ke-5 2016

Novianto, Anwar dan Ali Mustadi. (2015). Analisis Buku Teks Muatan Tematik Integratif, Scientific Approach, dan Authentic Assessment Sekolah Dasar. Jurnal Kependidikan, 45(1) Mei 2015.

Nur, Mohamad. (2000). Pengajaran Berpusat kepada Siswa dan Pendekatan Kontruktivis Dalam Pengajaran. Surabaya: Universitas Negeri Surabaya

Permendikbud. (2013). Implementasi Kurikulum. Jakarta: Menteri Pendidikan dan Kebudayaan Republik Indonesia

Pt. N., Ardana, I. K. , Agung, I. G. , \& Negara, O. (n. d.). 2014. Pengaruh Pembelajaran Mind Mapping Berbantuan Media Konkret Terhadap Hasil Belajar IPA Siswa Kelas V SD Gugus III Banjar Anyar Kediri Jurusan Pendidikan Guru Sekolah Dasar, FIP Universitas Pendidikan Ganesha

Rahayu, dkk. 2016. Penerapan Model Pembelajaran Berbasis Masalah (Pbm) Berbantuan Media Konkret Untuk MeningkatkanHasil Belajar Ipa. e-Journal PGSD Universitas Pendidikan Ganesha Jurusan PGSD. Vol 4 No 1.

Riyanto, Yatim. (2009). Paradigma Baru Pembelajaran. Jakarta: Kencana Prenada Media Group

Slameto. 2003. Belajar dan Faktor-faktor yang Mempengaruhinya. Jakarta: Rineka Cipta.

Sudjana, Nana. 1990. Teori-teori Belajar Untuk Pengajaran. Bandung: Fakultas Ekonomi UI.

Sugihartono. Dkk. (2007). Psikologi Pendidikan. Yogyakarta: UNY Pres

Suhito. 2018. Menumbuhkan Kemampuan Kognitif Dimensi Konseptual dalam Perkuliahan Geometri pada Jurusan Matematika FMIPA Unnes. PRISMA 1Journal Unnes, Vol 1(1), hIm (464-470).

Trianto. (2010). Mendesain Model Pembelajaran Inovatif-Progresif. Jakarta: Kencana Prenada Media Group

Widiana, dkk. (2014). Pembelajaran Berbasis Otak (Brain Based Learning), Gaya Kognitif Kemampuan Berpikir Kreatif Dan Pengetahuan konseptual Mahasiswa. Jurnal Mimbar PGSD Universitas Pendidikan Ganesha, 6(1)2. 
Widyani, Sadewi, dkk. 2017" The Discrepancy of Curriculum 2013 in Teaching and Learning Process Based on Permendikbud No 65 of 2013 in SD Laboratorium Undiksha". . Journal of Education Research and Evaluation. Vol. 1 (2) pp. 57-64. (Halaman 57). Diakses pada tanggal 05 Mei 2017

Yusuf dan Prabowo. 2019. Model Assesmen Pengetahuan Konseptual Mahasiswa Dalam Memecahkan Masalah Fisika. Jambura Physics Journal. Vol 1 No 1.

Saricayir, Hakan.,dkk. 2016. Determining Students' Conceptual Understanding Level of Thermodynamics. Journal of Education and Training Studies, Vol 4 (6), hlm 69-79.

Nugraha, Intan Siti \& Didi Suherdi. 2017. Scientific Approach: An English Learning-Teaching (Elt) Approach In The 2013 Curriculum. Journal of English and Education, Vol 5(2), hlm 112-119.

Firman, dkk. 2018. The Effectiveness of The Scientific Approach to Improve Student Learning Outcomes. International Journal of Active Learning, Vol 3(2), hlm 86-91.

F., \& Sani, R. (2016). Pengaruh Model Pembelajaran Kooperatif Tipe Group Investigation (Gi) Terhadap Pengetahuan Konseptual Siswa SMA Muhamadiyah 2 Medan T.P. 2015/2016. INPAFI (Inovasi Pembelajaran Fisika), 4(4). https://doi.org/10.24114/inpafi.v4i4.5635

Arisanti, W. O. L., Sopandi, W., \& Widodo, A. (2016). Analisis Penguasaan Konsep Dan Keterampilan Berpikir Kreatif Siswa Sd Melalui Project Based Learning. EduHumaniora, 8(1), 82-95.

Congdon, E. L., Kwon, M. K., \& Levine, S. C. (2018). Learning to measure through action and gesture: Children's prior knowledge matters. Cognition, 180(June), 182-190. https://doi.org/10.1016/j.cognition.2018.07.002

Dewi, P. S. (2016). Peta Konsep Sebagai Pendukung Pembelajaran dalam Memahami Pengetahuan Konsep Dasar IPA untuk Calon Guru Sekolah Dasar. Jurnal Pendidikan Dan Pembelajaran Dasar, 3, 386-407.

Flaig, M., Simonsmeier, B. A., Mayer, A. K., Rosman, T., Gorges, J., \& Schneider, M. (2018). Reprint of "Conceptual change and knowledge integration as learning processes in higher education: A latent transition analysis." Learning and Individual Differences, 66(November 2017), 92-104. https://doi.org/10.1016/j.lindif.2018.07.001

García Coni, A., Ison, M., \& Vivas, J. (2019). Conceptual Flexibility in School children: Switching Between Taxonomic and Thematic Relations. Cognitive Development, 52(August). https://doi.org/10.1016/j.cogdev.2019.100827

Windyariani, S. (2018). Kemampuan Literasi Sains Siswa SD Pada Konteks Melestarikan Capung. Biosfer: Jurnal Pendidikan Biologi, 10(1), 17-21. https://doi.org/10.21009/biosferjpb.10-1.3 